\title{
PENGARUH SISTEM MANAJEMEN MUTU TERHADAP KINERJA OPERASIONAL DI PT WASKITA BETON PRECAST
}

\author{
Miftakul Huda ${ }^{1}$, M. Luthfi Syifaul K. ${ }^{2}$ \\ miftakul.huda@pelitabangsa.ac.id ${ }^{1}$,mluthfi@gmail.com² \\ Program Studi Manajemen Universitas Pelita Bangsa
}

\begin{abstract}
ABSTRAK
Tujuan penelitian ini adalah menguji pengaruh sistem manajemen mutu terhadap kinerja operasional perusahaan di PT. Waskita Beton Precast. Data penelitian diperoleh dari sampel 100 responden karyawan yang dipilih secara acak serta proporsional pada setiap unit kerja. Metode analisa yang digunakan dalam menguji hubungan antar konstruk laten sistem manajemen mutu terhadap kinerja operasional perusahaan adalah Structural Equation Modeling (SEM) menggunakan program AMOS V.24. Hasil penelitian menemukan bahwa sistem manajemen mutu pada karyawan dipersepsikan sudah baik oleh karyawan. Hasil pengujian pada analisis full model, menunjukkan bahwa model secara keseluruhan memenuhi kriteria model fit. Keseluruhan indikator konstruk, yaitu fokus pada pelanggan, kepemimpinan, keterlibatan personel, pendekatan proses, pendekatan sistem terhadap menejemen, peningkatan berkesinambungan, pendekatan factual dalam mengambil keputusan, dan hubungan pemasok yang saling menguntungkan adalah valid dan reliabel dalam mengukur konstruk kinerja operasional perusahaan, serta pelanggan, tanggung jawab manajemen, realisasi produk, pengukuran analisa dan perbaikan adalah valid dan reliabel dalam mengukur konstruk pengaruh sistem manajemen mutu. Pengujian hipotesis menunjukkan hasil yang konsisten dengan kajian teoritis bahwa sistem manajemen mutu berpengaruh positif dan signifikan terhadap kinerja operasional perusahaan.
\end{abstract}

Kata Kunci : Sistem Manajemen Mutu, Kinerja Operasional

\section{PENDAHULUAN}

Perkembangan dunia industri jasa konstruksi di Indonesia akhir-akhir ini sangat pesat seiring dengan banyaknya pembangunan konstruksi seperti jalan tol, gedung, bendungan, maupun pekerjaan konstruksi lainnya. Dengan maraknya pembangunan tersebut maka dunia jasa konstruksi di Indonesia berlomba lomba untuk meningkatkan kualitas pelayanan dan kualitas / mutu pelaksanaan proyek proyek tersebut. Usaha memenangkan persaingan dengan meningkatkan kualitas sesuai dengan fungsinya, membutuhkan standarisasi yang disepakati dan diterima oleh pemerintah maupun pengguna jasa konstruksi. Salah satu standarisasi yang secara luas digunakan didunia, termasuk dalam bidang industri.

Industri konstruksi merupakan suatu kegiatan di sektor ekonomi yang melakukan transformasi berupa perencanaan, desain, keuangan, pengadaan, pembangunan, 
pengoperasian dan pemeliharaan dari berbagai sumber daya untuk menghasilkan fasilitas dan prasarana ekonomi dan sosial. Dalam perundang-undangan istilah industri konstruksi disebut sebagai jasa konstruksi. Menurut undang-undang Nomor 18 (1999 : Pasal 1 ayat 1), jasa konstruksi adalah layanan jasa yang meliputi layanan jasa konsultansi perencanaan pekerjaan konstruksi, layanan jasa pelaksanaan pekerjaan konstruksi, dan layanan jasa konsultansi pengawasan pekerjaan konstruksi.

Kegagalan pekerjaan konstruksi dapat disebabkan oleh kegagalan pelaksanaan atau penggunaan metode kerja yang tidak benar, penggunaan alat yang tidak sesuai dan penggunaan bahan yang tidak sesuai dengan spesifikasi dan standar yang sudah ditetapkan. Didasari hal tersebut, untuk meningkatkan mutu pekerjaan konstruksi, salah satu cara yang digunakan perusahaan-perusahaan konstruksi adalah dengan menerapkan sistem manajemen mutu, baik di dalam lingkup perusahaan maupun di dalam lingkup proyek (Asa, Abidin, dan Latif, 2009).

Pemberian pelayanan yang baik hanya bisa dicapai apabila kondisi internal perusahaan mendukung kinerja itu. Cara yang ditempuh dalam rangka kebijakan strategi bisnis untuk mengutamakan keunggulan adalah dengan meningkatkan kinerja operasional yang sesuai dengan standar mutu yang telah ditentukan. PT. Waskita Beton Precast. Hal itu merupakan upaya untuk memuaskan pelanggan dan selalu memenuhi kewajiban perjanjian dengan pelanggan, untuk memproduksi beton pra cetak, dengan standar mutu yang ditentukan. Berikut merupakan data rencana dan realisasi produksi beton pracetak tiang pancang dari PT. Waskita Beton Precast.

Tabel 1. Target Rencana dan Realisasi Produksi Tiang Pancang

Periode Bulan .Juni-Desember 2017

\begin{tabular}{llcc}
\hline NO & KETERANGAN & $\begin{array}{c}\text { RENCANA } \\
\text { PRODUKSI }\end{array}$ & $\begin{array}{c}\text { REALISASI } \\
\text { PRODUSKI }\end{array}$ \\
\hline 1 & Juni & 5,000 & 5,100 \\
2 & Juli & 5,000 & 5,740 \\
3 & Agustus & 5,000 & 4,500 \\
4 & September & 5,000 & 4,137 \\
5 & Oktober & 5,000 & 3,760 \\
6 & November & 5,000 & 4,250 \\
7 & Desember & 5,000 & 3,266 \\
\hline
\end{tabular}

Sumber : Data Primer Yang Diolah 
Data diatas menunjukkan bahwa realisasi produksi selama tujuh bulan tidak sesuai rencana yang ditetapkan perusahaan, serta terdapat kecenderungan terjadinya penyimpangan dari target yang ditentukan. Dengan adanya kekurangan jumlah untuk memenuhi produksi beton pracetak, maka dapat dipastikan terjadinya keterlambatan waktu penyelesaian perjanjian kerja kepada konsumen. Sebagai akibat dari keterlambatan itu, maka perusahaan menderita kerugian berupa denda, selain itu tingkat produksi yang tidak mencapai target akan mendorong peningkatan biaya operasional.

Tujuan dari penelitian ini mengungkapkan keinginan peneliti untuk memperoleh jawaban atas permasalahan penelitian yang diajukan. Berdasarkan latar belakang diatas maksud dan tujuan dari penelitian ini adalah untuk mengetahui pengaruh sistem manajemen mutu terhadap kinerja operasional di PT Waskita Beton Precast. Hal ini diperlukan dalam menetapkan strategi kualitas bagi PT. Waskita Beton Precast ke depannya.

\section{KAJIAN TEORI}

Menurut Vincent Gaspersz (2009), ISO 9001:2008 merupakan suatu kumpulan standar manajemen mutu dan standar proses, bukan standar produk. ISO 9001 : 2008 terdiri dari beberapa bagian yang memuat tentang sistem manajemen mutu, diantaranya ISO 9000:2000 dan ISO 9004:2000. ISO 9001:2008 berisikan persyaratan standar yang digunakan untuk mengukur kemampuan organisasi dalam memenuhi persyaratan pelanggan dan peraturan yang sesuai. ISO 9001:2008 berisikan pedoman standar yang menyediakan acuan dalam peningkatan berkelanjutan sistem manajemen mutu untuk memberikan keuntungan pada semua pihak, termasuk kepuasan pelanggan.

Dalam ISO 9001:2008 terdapat 8 ( delapan ) prinsip sistem manajemen mutu yang dijadikan sebagai acuan kerangka kerja yang membimbing organisasi menuju peningkatan kerja. Kedelapan prinsip sistem manajemen mutu yang terdapat dalam ISO 9001:2008, adalah :

1. Fokus pelanggan, pelanggan merupakan bagian yang sangat penting bagi organisasi, oleh sebab itu manajemen organisasi harus benar-benar memahami, memenuhi kebutuhan pelanggan saat ini dan yang akan datang bahkan melebihi harapan pelanggan.

2. Kepemimpinan, pemimpin sangat penting dalam menciptakan kesatuan arah dan 
tujuan organisasi, menciptakan dan mempertahankan lingkungan internal sehingga personel terlibat secara penuh untuk mencapai tujuan organisasi.

3. Keterlibatan personel, secara penuh pada semua tingkatan organisasi sangat penting sehingga kemampuan personel dapat digunakan untuk kepentingan organisasi.

4. Pendekatan proses, sangat penting untuk mencapai hasil yang diinginkan agar lebih efisien, dengan mengelola aktivitas dan sumber-sumber daya yang berkaitan sebagai suatu proses. Proses merupakan integrasi yang berurutan dari personel, material, metode, mesin, dan peralatan, dalam suatu lingkungan untuk menghasilkan keluaran yang memiliki nilai tambah bagi pelanggan.

5. Pendekatan sistem terhadap manajemen, merupakan Pengidentifikasian, pemahaman dan pengelolaan proses-proses yang saling berkaitan sebagai suatu sistem yang mendukung efektivitas dan efisiensi organisasi dalam mencapai tujuan-tujuannya.

6. Peningkatan berkesinambungan akan meningkatkan kinerja organisasi secara keseluruhan dan harus menjadi komitmen perusahaan. Peningkatan berkesinambungan merupakan suatu proses berkesinambungan untuk meningkatkan efektivitas dan efisiensi organisasi dalam memenuhi kebijakan dan mencapai tujuan organisasi.

7. Pendekatan faktual dalam pengambilan keputusan. Keputusan yang efektif harus berdasarkan analisis data dan informasi yang faktual, sehingga masalah-masalah mutu dapat terselesaikan secara efektif dan efisien. Keputusan yang diambil harus ditujukan untuk meningkatkan kinerja organisasi dan efektivitas implementasi sistem manajemen mutu.

8. Hubungan pemasok yang saling menguntungkan. Organisasi dan pemasokpemasoknya saling tergantung dan hubungan yang saling menguntungkan akan meningkatkan kemampuan bersama dalam menciptakan nilai tambah bagi pelanggan.

ISO 9001 merupakan standar sistim manajemen mutu yang berorientasi pada jaminan / pemastian mutu untuk memberi kepuasan pada pelanggan mulai dari kontrak hingga produk diserahkan. Standar ini memberikan penekanan pada sistim dokumentasi sebagai bentuk objektif dari suatu jaminan mutu. Disamping itu, ISO 
9001 menyediakan seperangkat panduan untuk dapat dilakukannya penerapan sistim manajemen mutu yang diakui secara internasional, sehingga mendorong standarisasi prosedur dan teamwork dalam organisasi perusahaan agar dapat menghasilkan mutu produk atau layanan jasa yang lebih baik dan sesuai dengan kebutuhan maupun harapan pelanggan.

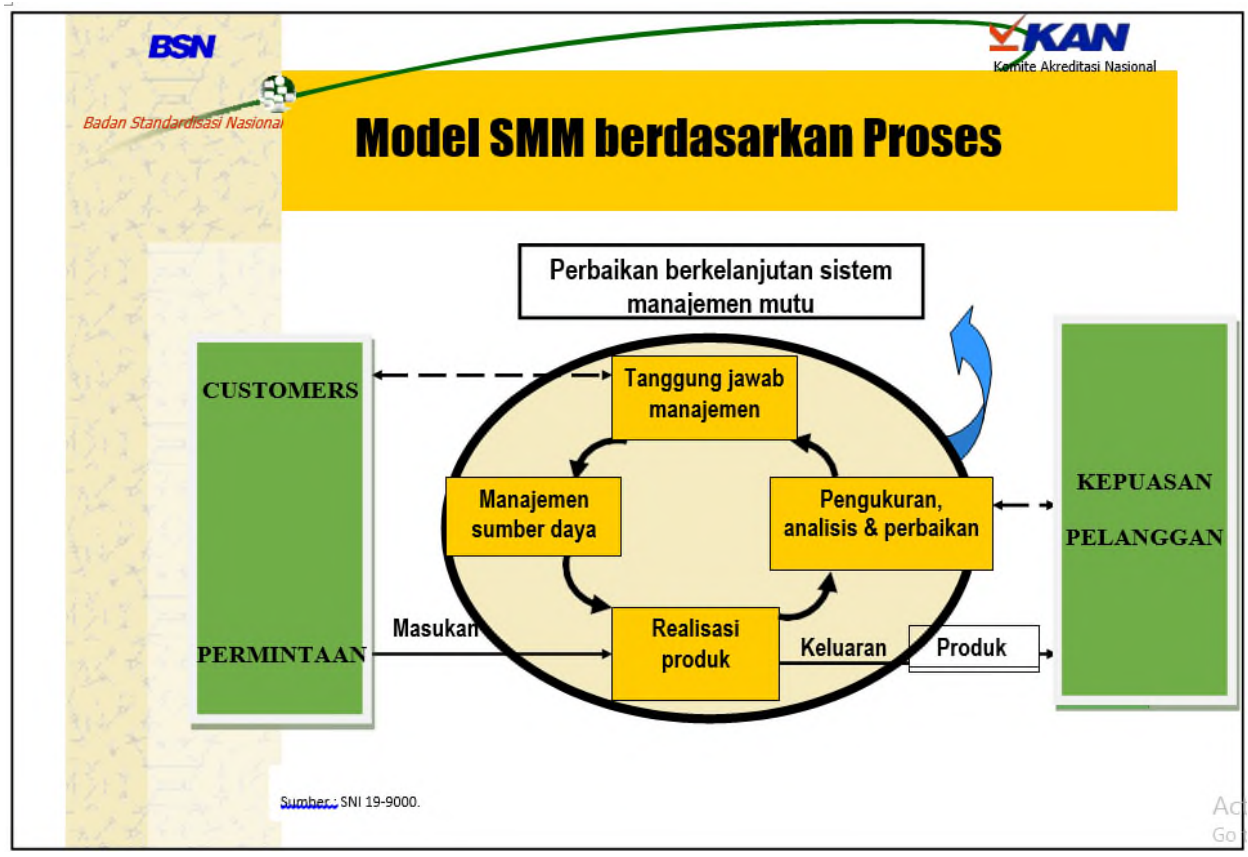

Gambar 1. Model Sistem Manajemen Mutu Berdasarkan Proses (Sumber : SNI 199000)

Menurut Mulyadi (2009), kinerja adalah keberhasilan dalam mewujudkan sasaran-sasaran strategik perusahaan dan sasaran strategik perusahaan ini merupakan hasil penerjemahan misi, visi, keyakinan dasar, nilai dasar, dan strategi perusahaan. Keberhasilan strategik yang dicapai organisasi atau perusahaan perlu diukur, oleh sebab itu sasaran strategik yang menjadi basis pengukuran kinerja perlu di tentukan ukurannya dan ditentukan inisiatif strategik untuk mewujudkanya. Pengertian kinerja menurut Moeheriono (2012:95) yaitu kinerja atau performance merupakan gambaran mengenai tingkat pencapaian pelaksanaan suatu program kegiatan atau kebijakan dalam mewujudkan sasaran, tujuan, visi dan misi organisasi yang dituangkan melalui perencanaan strategis suatu organisasi. Menurut Abdullah (2014:3) memberikan pengertian bahwa kinerja merupakan hasil pekerjaan yang mempunyai hubungan kuat dengan tujuan strategi organisasi, kepuasan konsumen dan memberikan kontribusi ekonomi. 
Wibowo (2007:7) menyebutkan bahwa kinerja berasal dari kata performance yang berarti hasil pekerjaan atau prestasi kerja. Namun perlu dipahami bahwa kinerja itu bukan sekedar hasil pekerjaan atau prestasi kerja, tetapi juga mencakup bagaimana proses pekerjaan itu berlangsung. Wirawan (2009:5) menyebutkan bahwa kinerja merupakan singkatan dari kinetika energi kerja yang padanannya dalam Bahasa Inggris adalah performance. Kinerja adalah keluaran yang dihasilkan oleh fungsifungsi atau indikator-indikator suatu pekerjaan atau suatu profesi dalam waktu tertentu.

Berdasarkan definisi manajemen operasi oleh para ahli diatas, dapat disimpulkan bahwa manajemen operasional adalah kegiatan yang berhubungan dengan perencanaan, pengkoordinasian, penggerakan dan pengendalian aktivitas organisasi atau perusahaan bisnis atau jasa yang berhubungan dengan proses pengolahan input menjadi output dengan nilai tambah yang besar.

\section{METODE PENELITIAN}

Jenis penelitian ini adalah asosiatif kausalitas, yakni mendeskripsikan tentang Sistem Manajemen Mutu dan kinerja operasional PT. Waskita Beton Precast. Penelitian kausalitas adalah penelitian yang ingin mencari penjelasan dalam bentuk hubungan sebab-akibat anatar beberapa konsep atau beberapa variabel atau beberapa strategi yang dikembangkan dalam manajemen. Penelitian ini diarahkan untuk menggambarkan sebab-akibat antara beberapa situasi yang digambarkan dalam variabel, dana atas dasar itu ditariklah sebuah kesimpulan umum.

Menurut Sugiyono (2005:11), asosiatif-kausal adalah penelitian yang mencari hubungan antara dua variabel atau lebih. Tujuan dari penelitian ini adalah untuk mencari hubungan antara satu variabel dengan variabel lain. Dan tujuan dari penelitian kausal adalah untuk mengidentifikasi hubungan sebab akibat antara variabel - variabel yang berfungsi sebagai penyebab dan variabel mana berfungsi sebagai variabel akibat.

Penelitian ini menggunakan pendekatan deskriptif dengan tujuan untuk mendeskripsikan objek penelitian atupun hasil penelitian. Adapun pengertian deskriptif menurut Sugiyono (2012) adalah metode yang berfungsi untuk mendeskripsikan atau memberi gambaran terhadap objek yang diteliti melalui data atau sampel yang telah 
terkumpul sebagimana adanya, tanpa melakukun analisis dan membuat kesimpulan yang berlaku umum.

Penelitian ini menggunakan dua macam variabel yang akan diteliti yaitu variabel independen (variabel bebas) dan variabel dependen (variabel terikat).

1. Variabel Bebas (independent variable) terdiri dari: Sistem Manajemen Mutu adalah program penjaminan kualitas yang sudah berlangsung di PT Waskita Beton Precast sebelum sertifikasi ISO diperoleh. Pada penelitian kali ini penulis menggunakan indikator yang ada pada ISO 9001:2000, tentang 8 (delapan) prinsip sistem manajemen mutu yang dijadikan sebagai acuan kerangka kerja yang membimbing organisasi menuju peningkatan kerja. Indikator-indikator yang berkaitan dengan sistem manajemen mutu adalah Fokus Pada Pelanggan, Kepemimpinan, Keterlibatan Personil, Pendekatan Proses, Pendekatan Sistem Terhadap Manajemen, Peningkatan Berkesinambungan, Pendekatan Faktual Dalam Pengambilan Keputusan, Hubungan Pemasok Yang Saling Menguntungkan.

2. Variabel terikat (dependent variable) Indikator-indikator yang digunakan untuk mengukur kinerja dalam variabel terikat (dependent variabel) penelitian ini diambil dari kriteria standar sistem manajemen mutu yang tercantum dalam ISO 9001:2008. Indikator-indikator tersebut adalah : Pelanggan, Tanggung Jawab Manajemen, Manajemen Sumber Daya, Realisasi Produk, Pengukuran, Analisa dan Perbaikan. Menurut Sugiyono (2009: 39) variabel independen (variabel bebas) adalah variabel yang mempengaruhi atau yang menjadi sebab perubahan atau timbulnya variabel dependen (terikat). Variabel bebas disebut sebagai variabel X, yaitu Sistem Manajemen Mutu, dengan variabel terikat atau disebut sebagai variabel Y, yaitu kinerja operasional. Indikator-indikator ini juga dihitung menggunakan skala interval dengan pilihan jawaban 'sangat tidak baik', tidak baik, 'cukup baik', 'baik', dan 'sangat baik'.

\section{HASIL DAN PEMBAHASAN}

\section{Analisa Data dan Pengujian Model Penelitian}

Proses analisis data dan pengujian model penelitian akan menjelaskan langkahlangkah analisis yang digunakan dalam penelitian ini. Langkah-langkah tersebut mengacu pada langkah-langkah proses analisis SEM sebagaimana dikemukakan oleh 
Dachlan (2014:203). Model penelitian yang berdasarkan kajian teori yang telah dilakukan sebelumnya, untuk melakukan pengujian mengenai pengaruh sistem manajemen mutu terhadap kinerja operasional perusahaan. Adapun urutan langkahlangkah analisis sebagai berikut.

\section{a. Pengembangan Diagram Jalur}

Diagram jalur merupakan penggambaran seluruh konstruk beserta indikatornya secara lengkap ke dalam suatu model diagram. Berdasarkan konstruk dan indikator yang telah diajukan sebelumnya, maka diagram jalur secara lengkap ditunjukkan pada gambar dibawah ini.

Konstruk yang membentuk penelitian ini telah dijelaskan pada bab sebelumnya, yaitu terdiri dari 1 variabel laten eksogen dengan 8 indikator serta 1 variabel laten endogen dengan 5 indikator. Model yang telah dinyatakan dalam diagram jalur tersebut akan dikonversikan dalam persamaan structural (Structural Equation) dan persamaan spesifikasi model pengukuran (Measure Model).

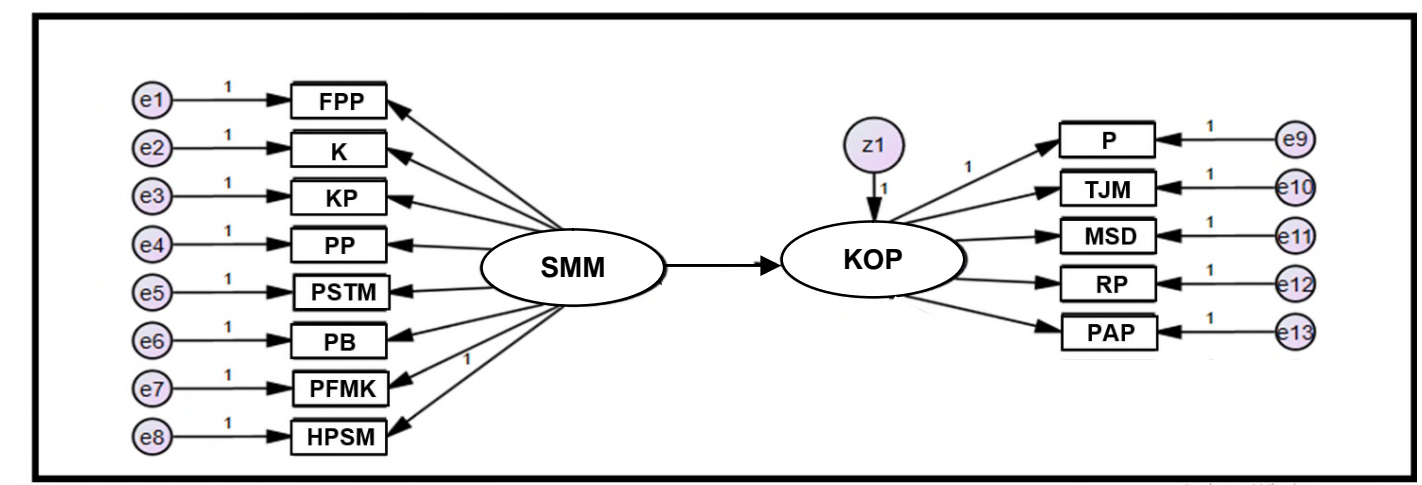

Data primer diolah (2018)

Gambar 4.6. Diagram Jalur

\section{b. Identifikasi Model}

Identifikasi model merupakan hal penting perlu diketahui sebelum sebuah model pengujian dilakukan. Sebuah model, estimasi dan pengujian model hanya dapat dilakukan jika model overidentified, yaitu memiliki derajat bebas (degree of freedom) lebih dari nol atau positif. Dari diagram jalur Gambar 5.1 memiliki :

$\mathrm{P}=13$ indikator

$\mathrm{k}=20$ parameter, yaitu factor loading $(\gamma)$ dan varians error $(\delta)$ dari setiap indikator.

Berdasarkan rumus, maka db dapat dihitung sebagai berikut : 
$\mathrm{db}=1 / 2.13 .(13+1)-20$

$\mathrm{db}=71(\mathrm{db}$ bernilai positif berarti model siap untuk diuji).

(1) Computation of degrees of freedom (Default model)

Number of distinct sample moments: 91

Number of distinct parameters to be estimated: 20

Degrees of freedom $(91-20)$ : 71

Gambar 4.7 Derajat Bebas Model

\section{c. Penilaian Normalitas Univariat dan Multivariat}

Berikut merupakan hasil pengujian normalitas data yang ditampilakan pada Tabel 4.27.

Tabel 2. Penilaian Normalitas Data

\begin{tabular}{|l|c|c|c|c|c|c|}
\hline \multicolumn{1}{|c|}{ Indikator konstruk } & Min & Mak & Skew & c.r & Kurotis & c.r \\
\hline Fokus Pada Pelanggan & 2,000 & 5,000 &, 135 &, 554 &, 417 &, 813 \\
\hline Kepemimpinan & 2,500 & 4,750 &, 221 &, 804 &, 174 &, 361 \\
\hline Ketelibatan Personel & 2,335 & 5,000 &, 381 & 1,616 &, 361 &, 804 \\
\hline Pendekatan Proses & 2,750 & 5,000 &, 057 &, 234 &, 118 &, 247 \\
\hline $\begin{array}{l}\text { Pendekatan Sistem Terhadap } \\
\text { Manjemen }\end{array}$ & 2,000 & 5,000 &, 291 & 1,163 &, 425 &, 935 \\
\hline $\begin{array}{l}\text { Peningkatan } \\
\text { Berkesinambungan }\end{array}$ & 2,000 & 5,000 &, 281 & 1,142 &, 121 &, 213 \\
\hline $\begin{array}{l}\text { Pendekatan Faktual Dalam } \\
\text { Mengambil Keputusan }\end{array}$ & 2,000 & 4,750 &, 372 & 1,541 &, 106 &, 211 \\
\hline $\begin{array}{l}\text { Hubungan Pemasok Yang } \\
\text { Saling Menguntungkan }\end{array}$ & 2,000 & 5,000 &, 164 &, 681 &, 672 & 1,414 \\
\hline Pelanggan dan & 2,500 & 5,000 &, 530 & 2,168 &, 020 &, 036 \\
\hline Tanggung Jawab Manajemen & 2,500 & 5,000 &, 433 & 1,778 &, 161 &, 342 \\
\hline Manajemen Sumber Daya & 3,000 & 5,000 &, 376 & 1,498 &, 918 & $-1,849$ \\
\hline Realisasi Produk & 2,500 & 2,750 &, 457 & 1,825 &, 761 & $-1,547$ \\
\hline $\begin{array}{l}\text { Pengukuran, Analisa dan } \\
\text { Perbaikan }\end{array}$ & 2,750 & 2,500 &, 223 &, 903 &, 415 &,- 811 \\
\hline Multivariat & & & & & 14,291 & 3,409 \\
\hline
\end{tabular}

Sumber : Data primer diolah (2018)

Dari tabel 4.27 diatas terlihat bahwa semua variabel observasi secara univariat tidak terdapat nilai CR (Critical Ratio) untuk Skewness dan kurtosis yang berada diluar rentang nilai $\pm 2,58$. Dengan demikian maka dapat dikatakan bahwa normalitas univariat data penelitian sudah terpenuhi. Koefisien kurtosis multivariat adalah sebesar 
3,409 atau dengan kata lain tidak terlalu jauh dari 2,58 yang berarti syarat normalitas multivariat terpenuhi. Data penelitian yang memenuhi normalitas multivariat berarti terpenuhinya asumsi :

a. Seluruh variabel memenuhi normalitas univariat.

b. Distribusi bersama untuk setiap sembarang pasang variabel memenuhi normalitas bivariat.

Dengan kata lain bahwa data dalam penelitian ini telah terdristibusi secara normal.

\section{Analisis Structural Equation Model}

Analisis selanjutnya adalah analisis Structural Equation Model (SEM) secara full model yang hasilnya ditunjukkan pada gambar 4.8. Pengujian model dalam Structural Equation Model dilakukan dengan dua pengujian, yaitu uji kesesuaian model (Goodness of Fit) dan uji signifikansi kausalitas melalui uji koefisien regresi.

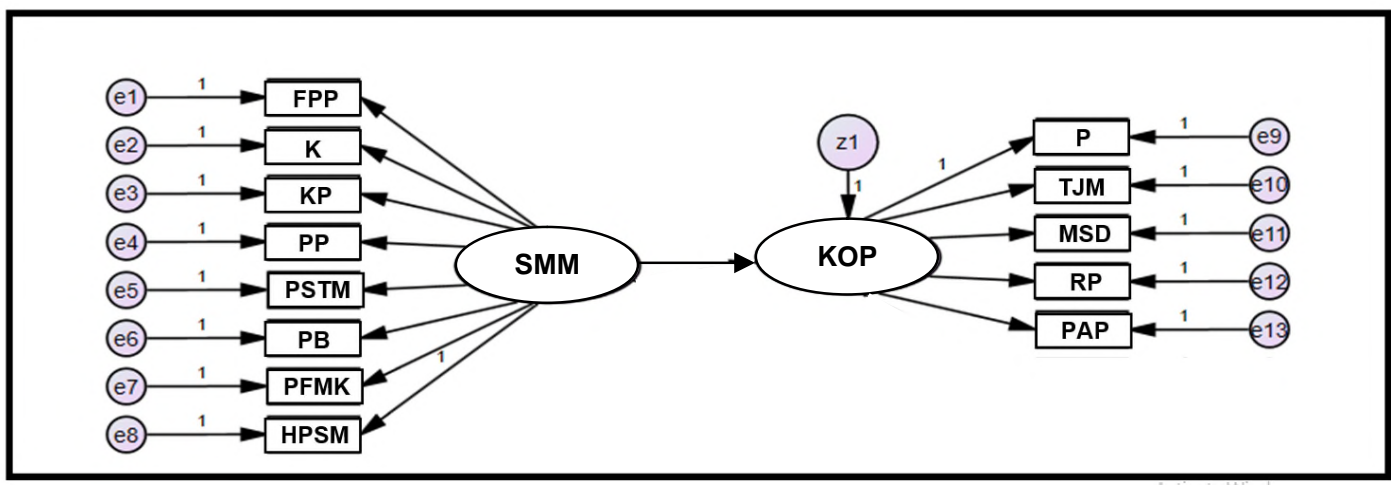

Sumber : Data primer diolah (2018)

\section{Gambar 2. Hasil Uji Structural Equation Model}

Berdasarkan hasil pengamatan pada Gambar 4.8 pada grafik analisis full model dapat ditunjukkan bahwa model memenuhi kriteria fit. Hal ini ditandai dengan nilai dari hasil perhitungan memenuhi kriteria layak full model. Hasil pengolahan data untuk analisis SEM ditunjukkan pada Tabel 4.29.

Hasil perhitungan uji chi square pada full model memperoleh nilai chi-square sebesar 91,28 yang masih dibawah chi-square tabel untuk derajat 71 pada tingkat signifikan 5\% sebesar 95,71. Nilai probabilitas sebesar 0,07 yang berarti nilai tersebut diatas 0,05. CMIN/DF sebesar 1,63 dan nilai tersebut berada dibawah nilai acuan $(\leq 3)$ yang menunjukkan tingkat kesesuaian model yang baik. Tingkat kesesuaian model yang baik tersebut menunjukkan tidak ada perbedaan antara model teoritis dengan data 
empiris yang berarti mendukung model sebagai perwakilan data (Hair et al.,h.666),atau dengan kata lain model yang diusulkan dalam penelitian ini sesuai dengan kenyataan.

Selanjutnya, model struktural pada penelitian ini menghasilkan nilai GFI sebesar 0,868. menurut Hair et al., (2010,h.667), semakin mendekati nilai 1 nilai GFI dianggap semakin baik dan diharapkan nilai GFI yang lebih besar atau sama dengan 0,90. Nilai GFI sebesar 0,868 dapat dikatakan nilai yang marjinal dan berdasarkan nilai penerimaan tersebut dapat disimpulkan bahwa secara keseluruhan model memiliki tingkat kesesuaian marjinal.

Selanjutnya, serupa dengan nilai GFI, semakin mendekati nilai 1 maka nilai AGFI dianggap semakin baik dan direkomendasikan nilai AGFI yang lebih besar atau sama dengan 0,90. Pada penelitian ini dihasilkan nilai AGFI sebesar 0,81 dan nilai tersebut dianggap dapat menunjukkan tingkat kesesuaian model yang marjinal.

Nilai RMSEA merupakan salah satu indeks ukuran badness-of-fit. Nilai RMSEA menunjukkan seberapa baik tingkat kesesuaian model jika diestimasikan dalam suatu populasi, tidak hanya pada sampel yang digunakan untuk estimasi (Hair et al., 2010, h.667). Semakin kecil nilai RMSEA menunjukkan tingkat kesesuaian yang semakin baik dan nilai penerimaan RMSEA berkisar antara 0,03 hingga 0,08 (Hair et al., 2010.h.667). Pada penelitian ini dihasilkan nilai RMSEA sebesar 0,07 dan nilai tersebut mencerminkan tingkat kesesuaian model yang baik.

Nilai TLI yang dihasilkan dari model struktural pada penelitian ini adalah sebesar 0,95 dan nilai tersebut dianggap mencerminkan tingkat kesesuaian model yang baik karena nilai TLI yang direkomendasikan adalah nilai TLI yang lebih besar atau sama dengan 0,90. Nilai TLI yang semakin mendekati nilai 1 menunjukkan tingkat kesesuaian model yang semakin baik jika dibandingkan dengan model null (Hair et al., 2010, h.668).

Terakhir nilai CFI yang dihasilkan dalam penelitian ini adalah sebesar 0,93. Karena nilai CFI yang direkomendasikan adalah lebih besar atau sama dengan 0,90 (Hair et al., 2010, h.669), maka dapat dikatakan model pada penelitian ini memiliki tingkat kesesuaian yang baik dibandingkan dengan model null. Pengujian kesesuaian model penelitian digunakan untuk menguji seberapa baik tingkat goodness of fit ditunjukkan padda Tabel 4.29. Berdasarkan hasil pengujian yang telah tersaji, diketahui dari enam kriteria yang ada. Meskipun terdapat nilai kesesuaian yang marginal pada 
GFI dan AGFI namun nilai tersebut tidak jauh beda dengan nilai kesesuaian lainnya, sehingga secara keseluruhan disimpulkan bahwa model struktural yang diestimasi dapat diterima (Ferdinand.A.T, 2014, h.260). Dengan hasil ini maka secara keseluruhan dapat dikatan bahwa model penelitian memiliki tingkat goodness of fit yang baik.

Tabel 3. Hasil Uji Full Model

\begin{tabular}{|c|c|c|c|}
\hline $\begin{array}{c}\text { Goodness of Fit } \\
\text { Indeks }\end{array}$ & Cut-off Value & Hasil Uji & $\begin{array}{c}\text { Keteranga } \\
\mathbf{n}\end{array}$ \\
\hline Chi Square & $\begin{array}{c}x^{2} \text { dengan df }: 71: \rho: 5 \% \\
=95,71\end{array}$ & 91,28 & Baik \\
\hline Probabilitas & $>0,05$ & 0,07 & Baik \\
\hline CMIN/DF & $\leq 3$ & 1,63 & Baik \\
\hline GFI & $\geq 0,90$ & 0,87 & Marginal \\
\hline AGFI & $\geq 0,90$ & 0,89 & Marginal \\
\hline TLI & $\geq 0,90$ & 0,93 & Baik \\
\hline CFI & $\geq 0,90$ & 0,95 & Baik \\
\hline RMSEA & $0,03-0,08$ & 0,07 & Baik \\
\hline
\end{tabular}

Sumber : Data primer diolah (2018)

Berdasarkan Tabel diatas, dapat diketahui bahwa observed (indikator) dari sistem manajemen mutu terhadap kinerja opeasional adalah valid karena mempunyai nilai $\lambda$ atau factor loading variabel laten terhadap indikatornya diatas 0,5 sehingga tidak satupun observed (indikator) yang di drop (dibuang).

\section{Uji Validitas dan Reabilitas}

\section{A. Uji Validitas}

Penilaian validitas menggunakan syarat :

a. Validitas konstruk yang mensyaratkan nilai CR bernilai diatas 1,96 dan p-value dua ekor (two tailed) dibawah 0,05 untuk signifikansi $5 \%$.

b. Validitas konvergen, yaitu menguji apakah indikator konstruk memiliki proporsi variance yang tinggi atau tidak. Memenuhi kriteria apabila Standardized Loading Estimate $(\lambda)$ atau factor loading diatas 0,7 .

Hasil pengujian validitas ditunjukkan pada Tabel 4.30. Keseluruhan indikator konstruk menunjukkan nilai Critical Ratio (CR) yang lebih besar dari 1,96, p-value lebih kecil dari 0,05 (tanda $* * *$ berarti bernilai $<0,001$ ). Hal tersebut menunjukkan bahwa semua indikator memenuhi validitas konstruk. Sedangkan setiap indikator konstruk memiliki proporsi variance dengan faktor loading > 0,7. Hal tersebut 
mengindikasikan bahwa seluruh indikator memenuhi validitas konvergen. Jadi kedelapan indikator penyerapan sistem manajemen mutu dan kelima indikator kinerja operasional dapat menjelaskan secara baik konstruk latennya, yang berarti valid.

Tabel 4. Hasil Pengujian Validitas

\begin{tabular}{|c|c|c|c|c|}
\hline $\begin{array}{c}\text { KONSTRUK } \\
\text { EKSOGEN }\end{array}$ & $\begin{array}{l}\text { KONSTRUK } \\
\text { ENDOGEN }\end{array}$ & C.R & $\mathbf{P}$ & $\begin{array}{c}\text { FACTOR } \\
\text { LOADIN } \\
G \\
\end{array}$ \\
\hline \multirow{9}{*}{$\begin{array}{c}\text { SISTEM } \\
\text { MANAJEMEN } \\
\text { MUTU }\end{array}$} & $\begin{array}{c}\text { Kinerja Operasional } \\
\text { Perusahaan }\end{array}$ & 8,603 & $* * *$ & 0,979 \\
\hline & Fokus Pada Pelanggan & 7,017 & $* * *$ & 0,895 \\
\hline & Kepemimpinan & 4,872 & $* * *$ & 0,754 \\
\hline & Keterlibatan Personel & 7,943 & $* * *$ & 0,786 \\
\hline & Pendekatan Proses & 7,662 & $* * *$ & 0,884 \\
\hline & $\begin{array}{c}\text { Pendekatan Sistem } \\
\text { Terhadap Manajemen }\end{array}$ & 7,033 & $* * *$ & 0,716 \\
\hline & $\begin{array}{c}\text { Peningkatan } \\
\text { Berkesinambungan }\end{array}$ & 7,455 & $* * *$ & 0,708 \\
\hline & $\begin{array}{c}\text { Pendekatan Faktual } \\
\text { Dalam Mengambil } \\
\text { Keputusan } \\
\end{array}$ & 7,926 & $* * *$ & 0,803 \\
\hline & $\begin{array}{l}\text { Hubungan Pemasok } \\
\text { Yang Saling } \\
\text { Menguntungkan } \\
\end{array}$ & 7,614 & $* * *$ & 0,804 \\
\hline \multirow{5}{*}{$\begin{array}{c}\text { KINERJA } \\
\text { OPERASIONAL } \\
\text { PERUSAHAAN }\end{array}$} & Pelanggan & 7,704 & $* * *$ & 0,852 \\
\hline & $\begin{array}{c}\text { Tanggung Jawab } \\
\text { Manajemen }\end{array}$ & 8,243 & $* * *$ & 0,791 \\
\hline & $\begin{array}{l}\text { Manajemen Sumber } \\
\text { Daya }\end{array}$ & 8,881 & $* * *$ & 0,832 \\
\hline & Realisasi Produk & 9,132 & $* * *$ & 0,870 \\
\hline & $\begin{array}{c}\text { Pengukuran, Analisa } \\
\text { dan Perbaikan }\end{array}$ & 7,327 & $* * *$ & 0,763 \\
\hline
\end{tabular}

Sumber : Data primer diolah (2018)

\section{B. Uji Reliabilitas}

Uji reliabilitas menunjukkan sejauh mana suatu alat ukur dapat memberikan hasil yang relatif sama apabila dilakukan pengukuran kembali pada obyek yang sama. Uji reliabilitas meliputi pengukuran Squared Multiple Correlation (SMC).

\section{Pengukuran Squared Multiple Correlation (SMC)}


Squared Multiple Correlation disimbolkan dengan $\mathrm{R}^{2}$, yang menjelaskan proporsi varians dari variabel dependen yang dapat dijelaskan oleh variabel-variabel independennya. Suatu indikator dikatakan reliabel apabila memiliki SMC >0.5 (Dachlan, 2014:192). Nilai SMC $\left(\mathrm{R}^{2}\right)$ yang diperoleh dari perhitungan AMOS ditunjukkan pada Tabel 4.31, yang menunjukkan semua indikator memiliki SMC diatas 0,5. hal ini menjelaskan bahwa semua indikator adalah reliabel dalam menjelaskan masing-masing konstruk latennya.

Tabel 5. Nilai Squared Multiple Correlation (SMC)

\begin{tabular}{|l|l|}
\hline \multicolumn{1}{|c|}{ KONSTRUK } & SMC \\
\hline Kinerja Operasional Perusahaan & 0,931 \\
\hline Fokus Pada Pelanggan & 0,768 \\
\hline Kepemimpinan & 0,612 \\
\hline Keterlibatan Personel & 0,635 \\
\hline Pendekatan Proses & 0,583 \\
\hline Pendekatan Sistem Terhadap Manajemen & 0,601 \\
\hline Peningkatan Berkesinambungan & 0,612 \\
\hline Pendekatan Faktual Dalam Mengambil Keputusan & 0,655 \\
\hline Hubungan Pemasok Yang Saling Menguntungkan & 0,636 \\
\hline Pelanggan & 0,775 \\
\hline Tanggung Jawab Manajemen & 0,604 \\
\hline Manajemen Sumber Daya & 0,701 \\
\hline Realisasi Produk & 0,727 \\
\hline Pengukuran, Analisa dan Perbaikan & 0,623 \\
\hline
\end{tabular}

Sumber : Data primer diolah (2018)

Berdasarkan Tabel diatas selain ditunjukkan oleh koefisien korelasi, kekuatan hubungan antar variabel laten ataupun laten terhadap indikatornya dinilai dari koefisien SMC $\left(\mathrm{R}^{2}\right)$. Koefisien Square Multiple Correlations atau SMC $\left(\mathrm{R}^{2}\right)$ merupakan proporsi varians dari variabel eksogen terhadap endogennya serta variabel laten terhadap indikatornya. Proporsi varian anatar variabel ditunjukkan pada Tabel 4.31 yaitu nilai Square Multiple Correlations (SMC).

\section{Interprestasi Model}

Setelah dilakukan berbagai pengujian, dari model yang telah dibuat, dapat diketahui hubungan yang ada diantaranya variabel dan indikatornya. Hubungan- 
hubungan tersebut dapat digunakan sebagai dasar dalam analisis suatu permasalahan. Hipotesis untuk pengujian antar variabel laten pada penelitian ini yaitu sebagai berikut: H0 : Tidak ada pengaruh antara variabel sistem manajemen mutu terhadap kinerja operasional perusahaan.

H1 : Terdapat pengaruh antara variabel sistem manajemen mutu terhadap kinerja operasional perusahaan.

Secara lengkap hasil regression Weight analisis Structural Equation Modeling ditunjukkan pada Tabel 6. Berdasarkan Tabel 6 dapat diketahui bahwa setiap indikator pembentuk variabel laten menunjukkan hasil yang memenuhi kriteria yaitu nilai CR diatas 2,58 dengan P lebih kecil dari pada 0,05. Hasil tersebut dapat dikatakan bahwa indikator-indikator pembentuk variabel laten tersebut secara signifikan merupakan indikator dari faktor-faktor laten yang dibentuk. Dengan demikian, model yang dipakai dalam penelitian ini dapat diterima.

Tabel 6. Regression Weights Analisis Structural Equation Modeling

\begin{tabular}{|c|c|c|c|c|c|}
\hline $\begin{array}{c}\text { KONSTRUK } \\
\text { EKSOGEN }\end{array}$ & $\begin{array}{l}\text { KONSTRUK } \\
\text { ENDOGEN }\end{array}$ & ESTIMATE & S.E & C.R & $\mathbf{P}$ \\
\hline $\begin{array}{c}\text { Sistem } \\
\text { Manajemen } \\
\text { Mutu }\end{array}$ & $\begin{array}{l}\text { Kinerja Operasional } \\
\text { Perusahaan }\end{array}$ & 0,721 & 0,114 & 7,203 & $* * *$ \\
\hline \multirow{8}{*}{$\begin{array}{l}\text { Sistem } \\
\text { Manajemen } \\
\text { Mutu }\end{array}$} & Fokus Pada Pelanggan & 0,723 & 0,130 & 6,931 & $* * *$ \\
\hline & Kepemimpinan & 1,105 & 0,129 & 6,817 & *** \\
\hline & Keterlibatan Personel & 1,061 & 0,122 & 7,652 & *** \\
\hline & Pendekatan Proses & 0,843 & 0,119 & 7,380 & $* * *$ \\
\hline & $\begin{array}{l}\text { Pendekatan Sistem } \\
\text { Terhadap Manajemen }\end{array}$ & 0,972 & 0,145 & 7,607 & *** \\
\hline & $\begin{array}{l}\text { Peningkatan } \\
\text { Berkesinambungan }\end{array}$ & 0,983 & 0,151 & 7,789 & $* * *$ \\
\hline & $\begin{array}{lr}\begin{array}{l}\text { Pendekatan } \\
\text { Dalam }\end{array} & \text { Faktual } \\
\text { Keputusan } & \\
\end{array}$ & 1,085 & 0,149 & 7,763 & $* * *$ \\
\hline & $\begin{array}{lr}\text { Hubungan } & \text { Pemasok } \\
\text { Yang } & \text { Saling } \\
\text { Menguntungkan }\end{array}$ & 1,000 & 0,132 & 6,603 & $* * *$ \\
\hline \multirow{5}{*}{$\begin{array}{c}\text { Kinerja } \\
\text { Operasional } \\
\text { Perusahaan }\end{array}$} & Pelanggan & 1,134 & 0,107 & 8,105 & *** \\
\hline & $\begin{array}{ll}\text { Tanggung } & \text { Jawab } \\
\text { Manajemen } & \end{array}$ & 1,143 & 0,120 & 8,790 & $* * *$ \\
\hline & $\begin{array}{l}\text { Manajemen Sumber } \\
\text { Daya }\end{array}$ & 1,114 & 0,127 & 9,104 & $* * *$ \\
\hline & Realisasi Produk & 1,107 & 0,132 & 7,327 & $* * *$ \\
\hline & $\begin{array}{ll}\begin{array}{l}\text { Pengukuran, } \\
\text { dan Perbaikan }\end{array} & \text { Analisa } \\
\end{array}$ & 1,000 & 0,132 & 7,363 & $* * *$ \\
\hline
\end{tabular}

Sumber : Data primer diolah (2018) 
Pengujian hipotesis ini adalah dengan menganalisis Critical Ratio (CR) dan nilai Probability $(\mathrm{P})$ hasil olah data, dibandingkan dengan batasan statistik yang disyaratkan, yaitu diatas 2,58 untuk nilai $\mathrm{CR}$ dan dibawah 0,05 untuk nilai $\mathrm{P}$ yang terdapat pada tabel Regression Weight. Berdasarkan Tabel 6 diketahui bahwa setiap peningkatan satu satuan variabel sistem manajemen mutu akan meningkatkan nilai sistem manajemen mutu sebesar 0,721. Untuk pengaruh variabel sistem manajemen mutu terhadap kinerja operasional perusahaan, memiliki nilai CR sebesar 7,203 yang berarti lebih tinggi dari 2,58 dan nilai $\mathrm{P}$ adalah sebesar (***) yang berarti dibawah 0,05 , maka dapat disimpulkan bahwa hipotesis nol (H0) yang menyatakan bahwa loading bernilai nol ditolak dan hipotesis H1 diterima. Dengan kata lain variabel sistem manajemen mutu berpengaruh secara signifikan terhadap kinerja operasional perusahaan. Pengaruh antar variabel ditunjukkan pada Tabel 7 di bawah ini :

Tabel 7. Interpretasi Pengaruh Antar Variabel

\begin{tabular}{|c|c|c|}
\hline $\begin{array}{l}\text { KONSTRUK } \\
\text { EKSOGEN }\end{array}$ & KONSTRUK ENDOGEN & $\begin{array}{l}\text { FACTOR } \\
\text { LOADING }\end{array}$ \\
\hline $\begin{array}{l}\text { Sistem Manajemen } \\
\text { Mutu }\end{array}$ & $\begin{array}{ll}\text { Kinerja } & \text { Operasional } \\
\text { Perusahaan } & \end{array}$ & Ada pengaruh \\
\hline \multirow{8}{*}{$\begin{array}{l}\text { Sistem Manajemen } \\
\text { Mutu }\end{array}$} & Fokus Pada Pelanggan & Ada hubungan \\
\hline & Kepemimpinan & Ada hubungan \\
\hline & Keterlibatan Personel & Ada hubungan \\
\hline & Pendekatan Proses & Ada hubungan \\
\hline & $\begin{array}{l}\text { Pendekatan Sistem Terhadap } \\
\text { Manajemen }\end{array}$ & Ada hubungan \\
\hline & $\begin{array}{l}\text { Peningkatan } \\
\text { Berkesinambungan }\end{array}$ & Ada hubungan \\
\hline & $\begin{array}{l}\text { Pendekatan Faktual Dalam } \\
\text { Mengambil Keputusan }\end{array}$ & Ada hubungan \\
\hline & $\begin{array}{ll}\text { Hubungan Pemasok } & \text { Yang } \\
\text { Saling Menguntungkan } & \\
\end{array}$ & Ada hubungan \\
\hline \multirow{5}{*}{$\begin{array}{l}\text { Kinerja Operasional } \\
\text { Perusahaan }\end{array}$} & Pelanggan & Ada hubungan \\
\hline & Tanggung Jawab Manajemen & Ada hubungan \\
\hline & Manajemen Sumber Daya & Ada hubungan \\
\hline & Realisasi Produk & Ada hubungan \\
\hline & $\begin{array}{l}\text { Pengukuran, Analisa dan } \\
\text { Perbaikan }\end{array}$ & Ada hubungan \\
\hline
\end{tabular}

Sumber : Data primer diolah (2018) 


\section{Hubungan Variabel Laten Sistem Manajemen Mutu Dengan Indikatornya}

Indikator sistem manajemen mutu yang paling kuat hubungannya adalah fokus pada pelanggan dengan tingkat korelasi 0,865. Hal ini sangat sejalan dengan praktek yang dijalankan oleh manajemen PT. Waskita Beton Precast dalam menjaga kualitas dan kepuasan pelanggan. Manajemen PT. Waskita Beton Precast selalu menekankan pentingnya fokus pada pelanggan kepada seluruh karyawan, dan mengawasi setiap kualitas produk agar senantiasa dijaga dalam pekerjaannya sehari-hari. Selain itu, kinerja operasional perusahaan menyaratkan adanya keyakinan dalam penerapan kualitas untuk kepuasan pelanggan.

Pada sisi lain, penekanan pada peningkatan berkesinambungan belum sepenuhnya mampu menjadikan komitmen dalam pencapaian kinerja yang maksimal pada karyawan PT. Waskita Beton Precast. Hal ini ditunjukkan oleh nilai korelasi sistem manajemen mutu terhadap indikator peningkatan berkesinambungan bernilai paling rendah dibandingkan indikator-indikator lainnya, yaitu dengan tingkat korelasi 0,708. Peningkatan berkesinambungan pada level karyawan maupun pekerja memerlukan usaha keras dan keteladanan yang baik dari seluruh pihak manajemen PT. Waskita Beton Precast, terutama atasan langsung yaitu kepala seksi dan manajer. Pada prakteknya karyawan kurang mendapatkan instruksi maupun masukan yang jelas menjadikan peningkatan kualitas dalam kinerja yang kurang maksimal. Melalui pengamatan pada beberapa karyawan dapat diketahui bahwa masih kurangnya pemahaman tentang standar operasi kerja yang bisa langsung dipahami oleh para pekerja maupun karyawan.

Indikator sistem manajemen mutu lain yang perlu mendapatkan perhatian adalah pendekatan sistem terhadap manajemen. Konstruk sistem manajemen mutu dijelaskan oleh indikator pendekatan sistem terhadap manajemen bernilai 0,716. Pemahaman karyawan PT. Waskita Beton Precast terhadap pendekatan sistem, dalam hal ini adalah standar prosedur kerja perusahaan masih perlu ditingkatkan. Harapan dalam pendekatan sistem terhadap manajemen di PT. Waskita Beton Precast supaya target produksi bisa selalu tercapai dan terjaga pada tiap tahun. Dan harapan kedepanya bisa meningkatkan kapasitas produksi pada tahun yang akan datang. Berdasarkan pengamatan, untuk memberikan pemahaman akan pendekatan sistem terhadap manajemen perusahaan masih kurang. 
Oleh karena itu diperoleh kesimpulan bahwa apabila pemahaman setiap karyawan PT. Waskita Beton Precast terhadap fokus pada pelanggan lebih baik, pemahaman karyawan akan perlunya peningkatan berkesinambungan, serta komitmen karyawan terhadap pendekatan sistem terhadap manajemen bisa menjadi terjalin dengan baik pada setiap karyawan, maka akan meningkatkan sistem manajemen mutu di PT. Waskita Beton Precast.

\section{Hubungan Variabel Laten Kinerja Operasional Perusahaan dengan Indikatornya}

Indikator konstruk keberhasilan kinerja operasional perusahaan yang paling kuat tingkat korelasinya adalah indikator pelanggan dengan tingkat korelasi 0,852 . Hubungan kerja dengan pelanggan sudah terbina dengan baik, melalui pencapaian target kerja dan kualitas yang dibutuhkan dari pelanggan. Hubungan dengan pelanggan yang baik dan jangka panjang akan menjamin keberlangsungan operasi bisnis perusahaan. Sedangkan tingginya korelasi penerapan prinsip kepada pelanggan karena memiliki tim operasional dan jaminan kualitas yang berasal dari beberapa departemen, sehingga selalu berusaha melibatkan semua pekerja maupun karyawan dalam pekerjaan yang berhubungan dengan kualitas. Komitmen karyawan dalam mensukseskan target bisnis perusahaan serta keterlibatan karyawan dalam aktifitas ide dan saran dirasakan oleh seluruh karyawan.

Sedangkan korelasi konstruk laten kinerja operasional perusahaan terhadap pengukuran, analisa dan perbaikan memiliki tingkat korelasi terendah yaitu 0,763 . Hal ini sejalan dengan permasalahan yang sedang dihadapai oleh PT. Waskita Beton Precast, yaitu adanya peningkatan produk offgrade dan terdapat klaim pelanggan. Korelasi yang paling rendah pada indikator ini mengindikasikan fokus terhadap pengukuran, analisa dan perbaikan terhadap kinerja maupun terhadap produk belum sepenuhnya dilakukan secara teratur, pengukuran, analisa dan perbaikan yang dilakukan belum tepat berdasarkan tingkat cacat dan adanya klaim pelanggan yang terjadi, dan belum semua karyawan secara penuh terlibat dalam pemeriksaan kualitas untuk lebih fokus terhadap perbaikan produk cacat. Korelasi kinerja operasional perusahaan terhadap tanggung jawab manajemen juga masih dalam tingkat kurang, yaitu 0,791. Hal 
ini menandakan pekerja maupun karyawan belum sepenuhnya mengetahui pencapaian kinerja dan kualitas produk terhadap tanggung jawab manajemen di perusahaan.

Hasil penelitian ini sejalan dengan penelitian yang dilakukan oleh Das (2008) bahwa kelima indikator pelanggan, tanggung jawab manajemen, manajemen sumber daya, realisasi produk, serta pengukuran, analisa dan perbaikan merupakan indikator yang reliabel dan valid untuk pembentukan konstruk Total Quality Management dalam perusahaan manufaktur, yang menemukan bahwa dimensi fokus pada pelanggan, peningkatan berkesinambungan dan pendekatan sistem terhadap manajemen memiliki korelasi tinggi terhadap variabel laten praktek TQM.

Jadi, dapat disimpulkan bahwa pemantauan terhadap keterlibatan pelanggan, tanggung jawab manajemen, manajemen sumber daya, realisasi produk, serta pengukuran, analisa dan perbaikan dapat mengukur keberhasilan penerapan sistem amanjemen mutu Iso 9001:2008 di PT. Waskita Beton Precast.

\section{KESIMPULAN DAN SARAN}

\section{Kesimpulan}

Berdasarkan hasil penelitian sistem manajemen mutu berpengaruh positif terhadap kinerja operasional di PT. Waskita Beton Precast. Setiap peningkatan satu satuan variabel kinerja operasional akan meningkatkan nilai sistem manajemen mutu sebesar 0,721 .

\section{Saran}

PT Waskita Beton Precast agar mensosialisasikan lebih lanjut terhadap karyawan mengenai pentingnya sistem manajemen mutu yang berpengaruh terhadap kinerja operasional perusahaan. Pengendalian sistem dan pembuatan role model agar karyawan lebih memahami tentang bagaimana peningkatan berkesinambungan dalam kinerja operasional. Dibuatkan planing audit internal sistem manajemen mutu pada perusahaan dua kali dalam setahun. Menjaga keterlibatan pegawai untuk menyadari dan mengetahui pentingnya sistem manajemen mutu di perusahaan.

PT. Waskita Beton Precast bisa lebih mensosialisasikan pemahaman tentang peningkatan berkesinambungan dalam hal ini adalah peningkatan kinerja operasional yang berkesinambungan. Peningkatan kinerja operasional dapat dilakukan melalui program-program seperti pengembangan sumber daya manusia tentang pelatihan sistem 
manajemen mutu, perlombaan Quality Control Cycle (QCC), dan pembentukan tim pengendalian mutu.

\section{DAFTAR PUSTAKA}

Abdullah, M. 2014. Manajemen dan Evaluasi Kinerja Karyawan. Yogyakarta : Penerbit Aswaja Pressindo

Dachlan, Usman. (2014). Panduan Lengkap Structural Equation Modeling. Lentera Ilmu. Semarang.

Dale, B. G., Ton Van Der Wiele dan Jos Iwarden. (2007). Managing Quality. John Wiley dan Sons. Oxford.

Gaspersz, Vincent. 2009. Total Quality Management (TQM). Jakarta: PT. Gramedia Pustaka Utama.

Goetsch, David I., dan Stanley B. Davis. (2014). "Quality Management for Organiztional Execellence. Pearson. New Jersey.

Ferdinand, Augusty. 2014. Metode Penelitian Manajemen. BP Universitas Diponegoro. Semarang.

Gryna, F. M., Richard Chim Hai Chua dan Joseph A. DeFeo. (2007). Juran's Quality Planning and Analysis for Enterprise Quality. New York.

Hair, J.F; W.C. Black; B.J. Babin; and R.E. Anderson (2010), Multivariate Data Analysis, 6th ed. Upper Saddle River, New Jersey: Pearson Education, Inc.

Heizer, Jay dan Barry Render. (2011). Operation Management, $10^{\text {th }}$ Edition. Pearson Prentice Hall.

Karimi, Yadollah, dan Sharifah Latifah S. A. K. (2012). “The Impact of Organizational Culture on The Implementational of TQM: Empirical Study in The Iranian Oil Company". American Journal of Industrial and Bussiness Management, 2(04), 205.

Kim, D. Y., Kumar, V., dan U. Kumar, (2011). “A Performance Realization Framework for Implementing ISO 9000”. International Journal of Quality and Reliability Management, 28(4), 383-404.

Lakhal, Lassaad. (2014). "The Relationship Between ISO 9000 Certification, TQM Practices, and Organizational Performance". The Quality Management Journal, 21(3), 38 .

Mail, A., Praktikto P., Sudjito S., Purnomo P., dan Budi S. (2014). "Relationship Between Internal Quality Audit and Quality Culture Toward Implementation Consistency of ISO 9000 in Private College of Sulawesi Province, Indonesia". International Education Studies, 7(9), p175.

Moeheriono. (2012). Pengukuran Kinerja Berbasis Kompetensi. Jakarta: PT Raja Grafindo Persada. 
Mulyadi. 2009. Sistem Terpadu Pengelolaan Kinerja Perusahaan Berbasis Balanced Scorecard. Yogyakarta: Unit Penerbit dan Perctakan STIM YKPN

Pangemanan, D. D. G. dan H. Tarore. (2013). "Faktor-faktor Yang Mempengaruhi Sistem Manajemen Mutu ISO 9001:2008 pada Perusahaan Kontraktor di Kota Manado”. Jurnal Ilmiah Media Engineering, 3(1).

Sugiyono. (2014). Metode Penelitian Bisnis. Alfabeta. Bandung.

Wibowo, 2007. Manajemen Kinerja. Jakarta : PT. Raja Grafindo Persada.

Wirawan. (2009). Evaluasi Kinerja Sumber Daya Manusia Teori Aplikasi dan Penelitian. Jakarta. Penerbit: Salemba Empat. 